\title{
CAD/CAM ZIRCONIA VS. SLIP-CAST GLASS-INFILTRATED ALUMINA/ZIRCONIA ALL-CERAMIC CROWNS: 2-YEAR RESULTS OF A RANDOMIZED CONTROLLED CLINICAL TRIAL
}

\author{
Murat Cavit ÇEHRELI ${ }^{1}$, Ali Murat KÖKAT ${ }^{2}$, Kivanç AKÇA ${ }^{3}$
}

\author{
1- DDS, PhD, Associate Professor, Section of Prosthodontics, CosmORAL Oral and Dental Health Polyclinics, Cinnah Cad. 7/5 06680 Kavaklidere, \\ Ankara, Turkey. \\ 2- DDS, PhD, Assistant Professor, Department of Prosthodontics, Faculty of Dentistry, Yeditepe University, Bagdat Str. No:238, 34728 Goztepe, \\ Istanbul. \\ 3- DDS, PhD, Associate Professor, Department of Prosthodontics, Faculty of Dentistry, Hacettepe University, 06100 Sihhiye, Ankara, Turkey.
}

Corresponding Address: Dr. Murat Cehreli - Section of Prosthodontics - CosmORAL Oral and Dental Health Polyclinics - Cinnah Cad. 7/5 06680 Kavaklidere - Ankara - Turkey - Phone: 90.312.4661406 - e-mail:mcehreli@ hotmail.com

Received: April 18, 2008 - Modification: June 17, 2008 - Accepted: June 19, 2008

\begin{abstract}
7 he Zirconia and CAD/CAMZirconia all-ceramic crowns. A total of $30 \mathrm{InCeram}^{\circledR}{ }^{\circledR}$ Zirconia and Cercon ${ }^{\circledR}$ Zirconia crowns were fabricated and cemented with a glass ionomer cement in 20 patients. At baseline, 6-month, 1-year, and 2-year recall appointments, Californian Dental Association (CDA) quality evaluation system was used to evaluate the prosthetic replacements, and plaque and gingival index scores were used to explore the periodontal outcome of the treatments. No clinical sign of marginal discoloration, persistent pain and secondary caries was detected in any of the restorations. All InCeram ${ }^{\circledR}$ Zirconia crowns survived during the 2-year period, although one nonvital tooth experienced root fracture coupled with the fracture of the veneering porcelain of the restoration. One Cercon $^{\circledR}$ Zirconia restoration fractured and was replaced. According to the CDA criteria, marginal integrity was rated excellent for InCeram ${ }^{\circledR}$ Zirconia (73\%) and Cercon ${ }^{\circledR}$ Zirconia (80\%) restorations, respectively. Slight color mismatch rate was higher for InCeram ${ }^{\circledR}$ Zirconia restorations $(66 \%)$ than Cercon $^{\circledR}$ Zirconia (26\%) restorations. Plaque and gingival index scores were mostly zero and almost constant over time. Time-dependent changes in plaque and gingival index scores within and between groups were statistically similar ( $\mathrm{p}>0.05$ ). This clinical study demonstrates that single-tooth InCeram ${ }^{\circledR}$ Zirconia and Cercon ${ }^{\circledR}$ Zirconia crowns have comparable early clinical outcome, both seem as acceptable treatment modalities, and most importantly, all-ceramic alumina crowns strengthened by $25 \%$ zirconia can sufficiently withstand functional load in the posterior zone.
\end{abstract}

Key words: Randomized Controlled trial. Aluminum oxide. Glass ionomer cements. Crowns. Dental ceramics.

\section{INTRODUCTION}

The traditional metal-fused-to-ceramic crowns have been challenged by the esthetic all-ceramic crown materials over the past decades, and the increasing demands for high esthetics coupled with biocompatibility and strength has resulted in an evolution in all-ceramic restorations ${ }^{2}$. The development of yttria-stabilized tetragonal zirconia polycrystal (Y-TZP) and transformation-toughening has led to a break-through in the field of esthetic full veneer restorations, and allowed the high-strength zirconia to be used for fabrication of fixed partial prostheses even in loadbearing regions ${ }^{8,26}$. The high temperature tetragonal phase in zirconia could be partially stabilized at room temperature by the addition of a secondary dopant phase as yttrium, ceria, calcium, magnesium, or titanium. In response to mechanical stimuli, the partially stabilized tetragonal phase transforms to monoclinic phase and the accompanying volumetric expansion (4\%) results in blunting the propagating crack tip and reduction in the incidence of mechanical failures in zirconia.

The InCeram ${ }^{\circledR}$ (Vita Zahnfabrik, Säckingen, Germany) ceramic system basically consists of a sintered aluminum oxide matrix infused with glass. The system is conventionally used as a core material in conjunction with a more translucent ceramic to enhance esthetic properties. The $\operatorname{InCeram}^{\circledR}$ Zirconia was developed later by incorporation of partially stabilized tetragonal zirconia into InCeram $^{\circledR}$ Alumina to improve the strength of the core material ${ }^{7}$. Similar to InCeram ${ }^{\circledR}$ Alumina, both the block and the slip material are 
infiltrated with specially developed VITA InCeram ${ }^{\circledR}$ Zirconia glasses and, like all other infiltration ceramics, veneered with VITAVM 7. The $\mathrm{Al}_{2} \mathrm{O}_{3}-\mathrm{ZrO}_{2}$-glass composite exhibits a markedly coarser microstructure with $\mathrm{Al}_{2} \mathrm{O}_{3}$ and $\mathrm{ZrO}_{2}$ grains in the size range $2-10 \mu \mathrm{m}$ embedded in a glass phase ${ }^{21}$. The relative amount of $\mathrm{Al}_{2} \mathrm{O}_{3}, \mathrm{ZrO}_{2}$ and glass phase in the composite is of approximately $55 \%, 25 \%$ and $20 \%$, respectively. The high-strength material is indicated for single tooth restorations in the anterior and posterior area and 3-unit bridges up to the molar area. Indeed, the clinical outcome of InCeram ${ }^{\circledR}$ Zirconia fixed prostheses is extremely high with very low episodes of failure in such use $\mathrm{e}^{10,21,24}$, although the available data for InCeram $^{\circledR}$ Zirconia restorations are still limited to draw reliable conclusions ${ }^{26}$.

The Cercon ${ }^{\circledR}$ Zirconia system (Dentsply DeguDent, Germany) is an Y-TZP ceramic. Y-TZP in the Cercon ${ }^{\circledR}$ system is a fully-dense polycrystalline material consisting of very small grains with size ranging from 200 to $300 \mathrm{~nm}^{20}$. During fabrication, conventional waxing techniques is undertaken for designing the zirconia infrastructure followed by scanning of the pattern, enlarging the digitized framework, and milling out of the pattern from a prefabricated homogeneous porous blank of zirconia using Cercon-smart ${ }^{\mathrm{B}}$ ceramics system. The zirconia pattern is then sintered to full density for $2 \mathrm{~h}$ at $1350^{\circ} \mathrm{C}$ to achieve the final infrastructure ${ }^{5,12}$. Using this CAD/CAM technique with the fully-dense core material, crowns as well as long-span fixed prostheses can be fabricated. While there is also a scarcity of evidence on the clinical evaluation of CAD/CAM Zirconia restorations, such restorations seem to have promising clinical outcome $\mathrm{e}^{14,18,22}$.

The purpose of this study was to explore the clinical effectiveness of InCeram ${ }^{\circledR}$ Zirconia and Cercon ${ }^{\circledR}$ Zirconia crowns. In this regard, a randomized comparative clinical study was designed and the crowns were assessed using the CDA quality evaluation system ${ }^{3}$ and plaque and gingival index scores were used to explore the periodontal outcome of the treatments ${ }^{11,16}$.

\section{MATERIAL AND METHODS}

\section{Subjects}

In this study, a total of 20 patients ( 9 male; 11 female; male mean age $=34.66$ years; female mean age $=37.45$ years $)$ participated. The data referring to the restored teeth are presented in Table 1. The patients were fully informed about the purposes and design of the clinical survey and consent was obtained prior to treatment. The patients were selected and recruited based on the following inclusion criteria: 1 . Extensive loss of tooth structure indicating full veneer crowns or crowns needing replacement (i.e., secondary caries, fracture); 2. Periodontal pocket depth less than $3 \mathrm{~mm}$; 3. No history of previous periodontal flap surgery; 4 . Good oral hygiene, low caries activity; 5 . No tooth mobility; 6 . Lack of excessive parafunctional activity leading to an extensive loss of tooth structure, abfraction lesions or cracks. Patients who had history of drug abuse and/or lifethreatening diseases (ASA Classification) ${ }^{1}$ or had implantsupported zirconia restorations were excluded from the study.

\section{Study Design}

This study was designed according to the CONSORT clinical trial guideline ${ }^{13}$. This is a randomized, controlled, single-blind (prosthodontist) two-arm clinical trial. The study goal was to compare the clinical outcome of InCeram ${ }^{\circledR}$ Zirconia and Cercon ${ }^{\circledR}$ Zirconia all-ceramic crowns. Owing to the high biocompatibility of Alumina and Zirconia and the high survival rate of InCeram ${ }^{\circledR}$ Alumina crowns ${ }^{27}$, it was hypothesized that the clinical outcome of crowns made by both materials, in terms of biocompatibility and rate of mechanical failures, would be comparable. The patients were screened according to the above-described inclusion/ exclusion criteria, and the eligible subjects were randomly assigned to one of the two groups (InCeram ${ }^{\circledR}$ Zirconia and Cercon ${ }^{\circledR}$ Zirconia) after an informed consent was granted. Randomization was performed by a clinical staff member blinded to the study content, by assigning each patient to the one of the groups by drawing like in chance games. As a sample size of 15 crowns was sufficient for statistical evaluation of the data gathered from periodontal assessment, the patient enrollment to the study was terminated when each group had 15 crowns.

\section{Study Procedures}

In all patients, the teeth were prepared with an occlusal/ incisal clearance of $2 \mathrm{~mm}$ and a deep chamfer $(1.5 \mathrm{~mm})$. The finish line was located approximately $0.5 \mathrm{~mm}$ subgingivally on the buccal side and at the gingival crest level in other sides during tooth preparation. Complete-arch impressions were made with a condensational polymerization silicone impression material (Speedex, Coltène AG, Altstätten, Switzerland), and irreversible

TABLE 1- Distribution and condition of teeth $(n=30)$ restored in 20 patients

\begin{tabular}{lcccc}
\hline & Vital & Nonvital & Replacements $^{*}$ & Total \\
\hline Maxillary premolar & 3 & 3 & 5 & 6 \\
Maxillary molar & 4 & 5 & 6 & 9 \\
Mandibular premolar & 2 & 5 & 2 & 7 \\
Mandibular molar & 7 & 1 & 6 & 8 \\
\hline
\end{tabular}

*Number of replacements for preexisting crowns. 
hydrocolloid impressions (Blueprint cremix, Dentsply DeTrey GmbH, Konstanz, Germany) were made of the opposing dentition. InCeram ${ }^{\circledR}$ Zirconia $(n=15)$ and Cercon ${ }^{\circledR}$ Zirconia $(n=15)$ crowns were fabricated according to the manufacturer's recommendations, and were cemented using a glass ionomer cement (Rely X, 3M Espe AG, Seefeld, Germany) (Fig. 1A and B). The patients were contacted by phone calls and were examined by a prosthodontist. Each restoration was assessed according to the CDA-quality evaluation system (Table 2$)^{3}$ and plaque ${ }^{11}$ and gingival ${ }^{18}$ index scores were also recorded at 6-month and annually thereafter.

\section{Statistical Analysis}

Intra-group comparisons for 6-month and annual plaque and gingival index scores were undertaken by Wilcoxon Signed Ranks Tests at a significance level set at $\mathrm{p}<0.05$. Inter-group comparisons for 6-month and annual plaque and gingival index scores were undertaken by Mann-Whitney U-tests at a significance level set at $\mathrm{p}<0.05$.

\section{RESULTS}

\section{Patient Population}

Twenty percent of the participants were smokers, $25 \%$ of the patients underwent tooth cleaning prior to prosthetic treatment, $45 \%$ of the participants did not have any signs

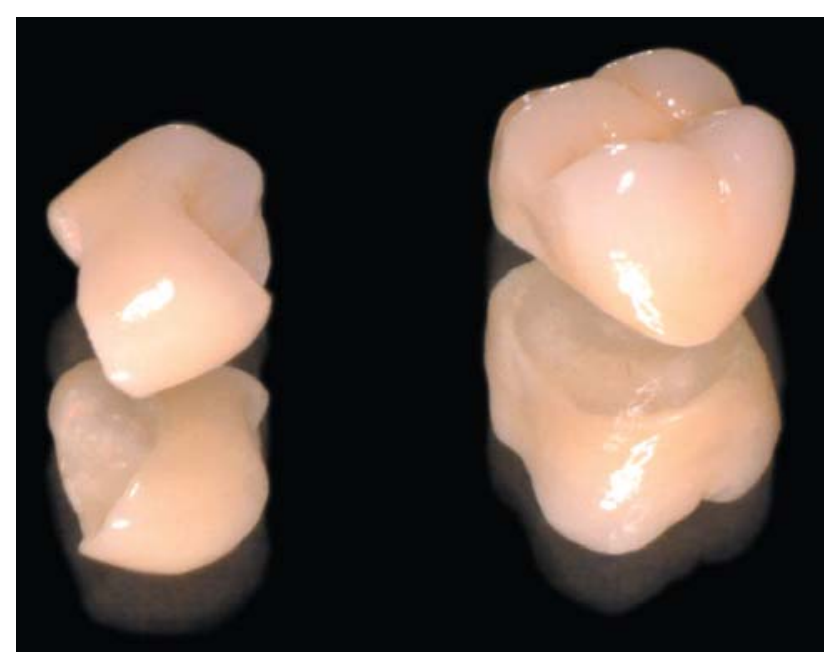

A

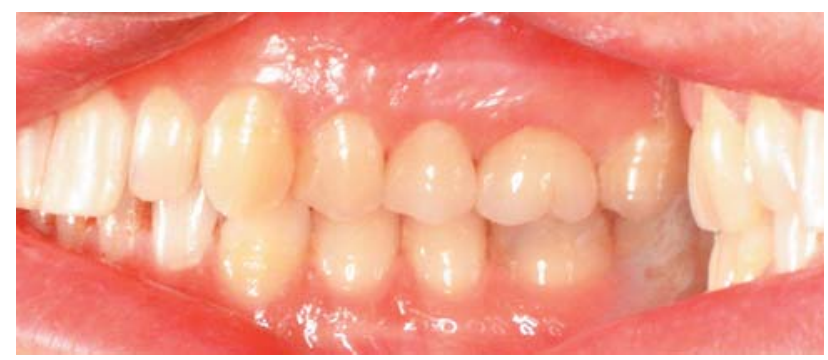

B

FIGURE 1- A. Cercon ${ }^{\circledR}$ Zirconia crowns for the maxillary right second premolar and first molar. B. In situ view of crowns immediately after cementation and symptoms of temporomandibular disorders, 30\% had nocturnal bruxism, but did not accept splint therapy, and the remaining $25 \%$ had nocturnal bruxism and received muscle-relaxation splints upon completion of prosthetic treatment. All patients attended the 6-month and annual recall appointments.

\section{CDA Evaluation}

CDA ratings are presented in Table 3. Marginal integrity was rated excellent for $73 \%$ of the InCeram ${ }^{\circledR}$ Zirconia and $80 \%$ of the Cercon ${ }^{\circledR}$ Zirconia restorations. Slight marginal discrepancy (SCR) was higher in the InCeram $^{\circledR}$ Zirconia group (26\%) than the Cercon ${ }^{\circledR}$ Zirconia (20\%) group. One of the Cercon ${ }^{\circledR}$ Zirconia restorations (maxillary 2nd molar) in a male patient fractured (VFR) in half (both core and veneering porcelain) 1 month after cementation and renewed. At the 1-year evaluation, one of teeth restored with InCeram ${ }^{\circledR}$ Zirconia crowns (mandibular 2nd premolar), fabricated on a titanium dowel and composite core in a female patient, fractured in the root (VTF) and the veneering porcelain of the restoration (VSF), and edema and bleeding on probing in the labial aspect of the tooth was evident. One Cercon ${ }^{\circledR}$ Zirconia restoration had SOCO, another had SUCO, and 2 restorations had slightly undercontoured marginal ridges. Four $(26 \%)$ InCeram ${ }^{\circledR}$ Zirconia restorations had SUCO, which did not lead to any periodontal problems. In $3(20 \%)$ InCeram $^{\circledR}$ Zirconia restorations, the patients experienced pain in the tooth for one to two weeks postcementation, which ceased totally thereafter. InCeram ${ }^{\circledR}$ Zirconia restorations had higher SMM $(66 \%)$ than Cercon ${ }^{\circledR}$ Zirconia (26\%) restorations. One InCeram ${ }^{\circledR}$ Zirconia and 2 Cercon $^{\circledR}$ Zirconia restorations had TMM, which was due to discoloration of adjacent tooth. At 2 years of function, CDA ratings were almost unchanged for all restorations, except for an InCeram ${ }^{\circledR}$ Zirconia restoration placed in a maxillary premolar, which had bone loss in the distal side and was scored VDM.

\section{Periodontal Outcome}

\section{Plaque Index}

Ten $(66.7 \%)$ InCeram $^{\circledR}$ Zirconia restorations had score $0,5(33.3 \%)$ had score 1 at 6-month and 1-year recalls, and the difference was non-significant statistically $(\mathrm{p}=1.00)$. Eleven $\left(73.3 \%\right.$ ) Cercon $^{\circledR}$ Zirconia restorations had score 0 and $4(26 \%)$ had 1 at 6-month recall appointment. At 1-year follow-up, $9(60 \%)$ restorations had score 0, 5 (33\%) had score 1 and 1 (6\%) was scored 2. Intra-group comparisons revealed no statistically significant difference between the 6-month and 1 -year plaque index data $(\mathrm{p}=0.083)$. Inter-group comparisons showed that the 6-month $(\mathrm{p}=0.775)$ and 1 -year $(p=0.683)$ data of both groups were comparable. After 2 years of follow-up, 9 InCeram $^{\circledR}$ Zirconia and Cercon ${ }^{\circledR}$ Zirconia crowns $(60 \%)$ had score 0 , and 6 crowns $(40 \%)$ had score 1 , the difference between groups being nonsignificant statistically $(\mathrm{p}=1.00)$. 
TABLE 2-California Dental Association rating criteria ${ }^{3}$

\begin{tabular}{|c|c|c|c|}
\hline $\begin{array}{c}\text { Category } \\
\text { Margin integrity }\end{array}$ & \multicolumn{2}{|c|}{ Score } & \multirow{2}{*}{$\begin{array}{l}\text { Criteria } \\
\text { No visible evidence of gap along the margin in which an } \\
\text { explorer could get stuck. No evidence of ditching along } \\
\text { margin. }\end{array}$} \\
\hline Margin integrity & $\begin{array}{l}\text { Acceptable } \\
\text { Excellent }\end{array}$ & Unacceptable & \\
\hline & SCR & & $\begin{array}{l}\text { Visible evidence of slight marginal discrepancy with no } \\
\text { evidence of decay. Repair is possible, but perhaps } \\
\text { unnecessary. Explorer gets stuck in one direction. }\end{array}$ \\
\hline & & TFAM & Faulty margins that cannot be properly repaired. \\
\hline & & TPEN & $\begin{array}{l}\text { Penetrating discoloration along the margin of restoration in } \\
\text { pulpal direction }\end{array}$ \\
\hline & & TCEM & Retained excess cement \\
\hline & & VMO & Mobile restoration \\
\hline & & VFR & Fractured restoration \\
\hline & & VCAR & Caries continuous with the restoration margin \\
\hline & & VTF & Fractured tooth structure \\
\hline \multirow[t]{17}{*}{ Anatomic form } & Excellent & & $\begin{array}{l}\text { Restoration contour in functional harmony with adjacent } \\
\text { teeth and soft tissues within good individual anatomic form. }\end{array}$ \\
\hline & SOCO & & Slightly overcontoured restoration \\
\hline & SUCO & & Slightly undercontoured Restoration \\
\hline & $\mathrm{SOH}$ & & Occlusion not completely functional \\
\hline & SMR & & Slightly undercontoured margin ridges \\
\hline & SCO & & Contact slightly open. \\
\hline & SFA & & Facial flatting present. \\
\hline & SLG & & Lingual flatting present. \\
\hline & & TUCO & Grossly undercontoured restoration \\
\hline & & TOCO & Grossly overcontoured restoration \\
\hline & & TET & Impaired occlusion affected \\
\hline & & TOC & Faulty contact \\
\hline & & TOV & Marginal overhang present. \\
\hline & & VTO & Traumatic occlusion. \\
\hline & & VUO & Gross underocclusion \\
\hline & & VPN & $\begin{array}{l}\text { Restoration caused unremitting pain in tooth or adjacent } \\
\text { tissue. }\end{array}$ \\
\hline & & VDM & Damage to tooth, soft tissue, or supporting bone. \\
\hline \multirow[t]{8}{*}{ Color and surface } & Excellent & & $\begin{array}{l}\text { No mismatch in color shade and/or translucency between } \\
\text { restoration(s) and adjacent teeth. Smooth restoration } \\
\text { surface. No irritation of adjacent tissues. }\end{array}$ \\
\hline & SMM & & $\begin{array}{l}\text { Slight mismatch between shade of restoration(s) and } \\
\text { adjacent tooth or teeth. }\end{array}$ \\
\hline & SRO & & Restoration surface is slightly rough but can be polished. \\
\hline & & TGI & $\begin{array}{l}\text { Grossly irregular surface not related to anatomy and not } \\
\text { subject to correction }\end{array}$ \\
\hline & & TMM & $\begin{array}{l}\text { Mismatch between restoration(s) and adjacent tooth or teeth } \\
\text { without normal range of color, shade, and/or translucency }\end{array}$ \\
\hline & & VSF & Fractured surface. \\
\hline & & VGP & Gross porosities in crown material. \\
\hline & & VSD & Shade in gross disharmony with adjacent teeth. \\
\hline
\end{tabular}


TABLE 3- California Dental Association ratings for InCeram ${ }^{\circledast}$ and Cercon ${ }^{\circledast}$ restorations at the 1-year follow-up period

\begin{tabular}{|c|c|c|c|c|c|c|c|c|c|}
\hline \multicolumn{10}{|c|}{ Number of Crowns (and \%) } \\
\hline & \multirow[t]{2}{*}{ Rating } & \multicolumn{2}{|c|}{ Baseline } & \multicolumn{2}{|c|}{ 6-month recall } & \multicolumn{2}{|c|}{ 1-year recall } & \multicolumn{2}{|c|}{ 2-year recall } \\
\hline & & InCeram $^{\circledR}$ & Cercon $^{\circledR}$ & InCeram $^{\circledR}$ & Cercon $^{\circledR}$ & InCeram $^{\circledR}$ & Cercon $^{\circledR}$ & InCeram $^{\circledR}$ & Cercon $^{\circledR}$ \\
\hline Margin & Excellent & 13(86) & 14(93) & $11(73)$ & $12(80)$ & $11(73)$ & $12(80)$ & $11(73)$ & $12(80)$ \\
\hline \multirow[t]{3}{*}{ Integrity } & SCR & $2(13)$ & $1(6)$ & $4(26)$ & $2(13)$ & $4(26)$ & $2(13)$ & $4(26)$ & $2(13)$ \\
\hline & VFR & - & - & - & $1(6)$ & - & $1(6)$ & - & $1(6)$ \\
\hline & VTF & - & - & - & - & $1(6)$ & - & $1(6)$ & - \\
\hline Anatomic & Excellent & $11(73)$ & $11(73)$ & $11(73)$ & $11(73)$ & $11(73)$ & $11(73)$ & $11(73)$ & $11(73)$ \\
\hline \multirow[t]{5}{*}{ Form } & SOCO & - & $1(6)$ & - & $1(6)$ & - & $1(6)$ & - & $1(6)$ \\
\hline & SUCO & $4(26)$ & $1(6)$ & $4(26)$ & $1(6)$ & $4(26)$ & $1(6)$ & $4(26)$ & $1(6)$ \\
\hline & SMR & - & 2 (13) & - & 2 (13) & - & $2(13)$ & - & $2(13)$ \\
\hline & VDM & - & - & - & - & - & - & $1(6)$ & - \\
\hline & VPN & $3(20)$ & - & $3(20)$ & - & $3(20)$ & - & $3(20)$ & - \\
\hline Color and & Excellent & $4(26)$ & $9(60)$ & $4(26)$ & $9(60)$ & $4(26)$ & $9(60)$ & $4(26)$ & $9(60)$ \\
\hline \multirow[t]{3}{*}{ Surface } & SMM & $10(66)$ & $4(26)$ & $10(66)$ & $4(26)$ & $10(66)$ & $4(26)$ & $10(66)$ & $4(26)$ \\
\hline & TMM & $1(6)$ & $2(13)$ & $1(6)$ & $2(13)$ & $1(6)$ & 2 (13) & $1(6)$ & $2(13)$ \\
\hline & VSF & - & - & - & - & $1(6)$ & - & $1(6)$ & - \\
\hline
\end{tabular}

\section{Gingival Index}

Thirteen $(86.7 \%)$ InCeram ${ }^{\circledR}$ Zirconia restorations had score $0,1(6.7 \%)$ received score 1 , and 1 crown had (6.7\%) score 2 at the 6-month recall. Twelve $(80 \%)$ restorations had score $0,2(13.3 \%)$ were scored 1 , and $1(6.7 \%)$ received score 2 at the 1-year recall. At the 2-year recall, $11(73.3 \%)$ restorations were scored 0 and $4(26.7 \%)$ were scored 1. The difference between the 6-month and 1-year recall data was non-significant statistically $(\mathrm{p}=0.317)$. Fourteen $(93.3 \%)$ Cercon ${ }^{\circledR}$ Zirconia restorations had score 0 , and $1(6.7 \%)$ had score 1 at 6-month, 1-year, and 2-year recall appointments, without statistical significance among the periods ( $\mathrm{p}=1.00)$. Inter-group comparisons revealed that the 6-month $(\mathrm{p}=0.744), 1$-year $(\mathrm{p}=0.539)$, and 2-year $(\mathrm{p}=0.367)$ data of both groups were comparable.

\section{DISCUSSION}

As far as it could be ascertained, this study is the first randomized controlled clinical trial to make a comparative evaluation of Zirconia crowns, and the obtained results indicate that the early prosthetic and periodontal response to both InCeram ${ }^{\circledR}$ Zirconia and Cercon ${ }^{\circledR}$ Zirconia crowns were similar. The unit of analysis in previous clinical studies on all-ceramic crowns ${ }^{4,6,18}$ were the exceptionality of location, uniqueness in preparation, and morphology of crowns placed in the same individual, rather than in different patients, and therefore, the same approach was followed for the statistical analysis of the periodontal data of the crowns.

With regard to the mechanical outcome, the very low and comparable failures, 1 VFR for Cercon ${ }^{\circledR}$ Zirconia and 1 VTF coupled with VSF for InCeram ${ }^{\circledR}$ Zirconia is a promising result. It is well known that the strength of an all-ceramic crown is significantly influenced by the type of ceramic material and luting cement ${ }^{9}$ used, and the occlusal loading imposed to the crown. Because all crowns in the study were fabricated in the posterior zone and were cemented with the same material, possible mechanical failures would be attributed to the ceramic system tested.

A comparative evaluation of the mechanical strength of slip-cast glass-infiltrated InCeram ${ }^{\circledR}$ Alumina/Zirconia and Cercon ${ }^{\circledR}$ Zirconia revealed that the biaxial flexural strength of the materials were $541.80 \mathrm{~N}$ and $1140.89 \mathrm{~N}$, respectively ${ }^{26}$. In addition, another study on 4-unit bridges revealed that Cercon $^{\circledR}$ Zirconia bridges had higher (706 \pm $123 \mathrm{~N})$ load-bearing capacity than milled-out InCeram $^{\circledR}$ Alumina/Zirconia bridges $(470 \pm 101 \mathrm{~N})^{12}$. Therefore, one could presume that a material having half of the flexural strength of another would experience more mechanical failures. However, the failure rate of the InCeram ${ }^{\circledR}$ Zirconia crowns (one crown: VSF- 6.7\%) was not attributed to the restorative material whatsoever, but the failure of the postcore restoration and root fracture. This implies that the mechanical strength of InCeram ${ }^{\circledR}$ Zirconia, which has only $25 \%$ Y-TZP content compared to the fully-dense Y-TZP structure of Cercon ${ }^{\circledR}$ Zirconia, surpasses the critical threshold for survival as a "crown" in the posterior zone. The fractured Cercon $^{\circledR}$ Zirconia restoration was also fabricated on a nonvital tooth, but without a post-core restoration, the patient had nocturnal bruxism and had undergone muscle-relaxation splint therapy for a long period of time. This crown was 
immediately replaced and no other mechanical failures were reported for any of the Cercon ${ }^{\circledR}$ Zirconia crowns during the 1-year evaluation period. SCR was observed for both InCeram ${ }^{\circledR}$ Zirconia and Cercon ${ }^{\circledR}$ Zirconia restorations at a rate of $26 \%$ and $13 \%$, respectively. This finding is in line with results of other studies about all-ceramic crowns. For example, Gemalmaz and Ergin reported 19\% SCR for IPS Empress crowns ${ }^{6}$, while Naert, et al. ${ }^{14}$ reported $18 \%$ SCR and 2 unacceptable margins for Procera all-ceramic crowns.

In the present study, none of the SCR sites experienced gingival recession, pocket formation, bleeding on probing (except for the fractured root), painful symptomatology, marginal leakage, and consequent secondary caries during the 1-year follow up period. No cement washout was detected for any of the restorations, although recementation of one InCeram ${ }^{\circledR}$ Zirconia restoration was required due to cement failure (adhesive failure to zirconia). The high SMM rate for InCeram ${ }^{\circledR}$ Zirconia was not solely due to the fabrication of the crowns, but frequently to adjacent amalgam restorations that led to grayish discoloration of those teeth. Although it was not considered a parameter during the comparative analysis of the crowns, longer chairside time was frequently required for the marginal fit adjustments of Cercon ${ }^{\circledR}$ Zirconia crowns. Cercon ${ }^{\circledR}$ Zirconia crowns frequently experienced a premature contact zone, particularly in one or two axial surfaces of the crowns, which did not coincide to an edge or a cusp tip. A study on the marginal adaptation of CAD/CAM generated zirconia bridges demonstrated that the median of marginal adaptation of zirconia bridges were $75 \mu \mathrm{m}$ for Digident ${ }^{\circledR}, 65 \mu \mathrm{m}$ for Lava ${ }^{\circledR}$ and Cerec Inlab ${ }^{\circledR}$ zirconia systems, and $54 \mu \mathrm{m}$ for the traditional metal-fused-to-porcelain fixed partial prostheses ${ }^{16}$. The misfit in the occlusal surface of these restorations reached $326 \mu \mathrm{m}$ for Digident ${ }^{\circledR}, 198 \mu \mathrm{m}$ for $\mathrm{Lava}^{\circledR}, 359 \mu \mathrm{m}$ for Cerec Inlab ${ }^{\circledR}$, and $287 \mu \mathrm{m}$ for metalceramic restorations, which indicated unevenness in misfit. As misfit in the axial wall area and occlusal plateau can reduce the resistance to fracture of all-ceramic restoration ${ }^{23}$, the discrepancy is a very critical issue for the survival of the restoration. The reason for (premature) contact in the axial wall rather than the occlusal surface of Cercon ${ }^{\circledR}$ Zirconia restorations could be attributed to the fact that, like other $\mathrm{CAD} / \mathrm{CAM}$ systems, the grinding process probably affects the internal adaptation. Structures that are smaller than the narrowest bur diameter may be removed during the CAM process.

So far, there has been no clinical study dedicated specifically to explore the clinical outcome of InCeram ${ }^{\circledR}$ Zirconia and/or Cercon ${ }^{\circledR}$ Zirconia crowns, which means that the results of the present clinical trial cannot be compared to previously published data. The plaque and gingival index scores and their time-dependent change for both materials were very low over time, and the outcome was comparable between the groups. The InCeram ${ }^{\circledR}$ Zirconia crown that received score 2 for gingival index in the 6-month recall was the mandibular premolar restoration that sustained root fracture (VTF) and fracture of the porcelain (VSF) at the 1year evaluation. This finding reveals that within 1-year, soft tissue reaction adjacent to InCeram $^{\circledR}$ Zirconia and Cercon ${ }^{\circledR}$ Zirconia crowns are almost the same. In addition, the very stable and healthy soft tissue outcome coupled with no signs of marginal discoloration and tooth sensitivity demonstrates that the marginal adaptation of InCeram ${ }^{\circledR}$ Zirconia and Cercon ${ }^{\circledR}$ Zirconia crowns were within clinically acceptable limits.

\section{CONCLUSION}

The following conclusions may be drawn: 1. The 1-year results of this randomized controlled clinical trial reveals that single-tooth InCeram ${ }^{\circledR}$ Zirconia and Cercon ${ }^{\circledR}$ Zirconia crowns have similar prosthetic and periodontal outcome and both seem as acceptable treatment modalities for replacement of posterior teeth. 2. All-ceramic alumina crowns strengthened by $25 \%$ zirconia can sufficiently withstand functional load in the posterior zone.

\section{REFERENCES}

1- American Society of Anesthesiologists. New classification of physical status. Anesthesiol. 1998;234:111.

2- Anusavice KJ. Degradability of dental ceramics. Adv Dent Res. 1992;6:82-9.

3- California Dental Association. Quality evaluation for dental care. Guidelines for the assessment of clinical quality and professional performance. Los Angeles: California Dental Association; 1977.

4- Erpenstein H, Borchard R, Kerschbaum T. Long-term clinical results of galvano-ceramic and glass-ceramic individual crowns. J Prosthet Dent. 2000;83:530-4.

5- Filser F, Kocher P, Weibel F, Luthy H, Scharer P, Gauckler LJ. Reliability and strength of all-ceramic dental restorations fabricated by direct ceramic machining (DCM). Int J Comput Dent. 2001;4:89-106.

6- Gemalmaz D, Ergin S. Clinical evaluation of all-ceramic crowns. J Prosthet Dent. 2002;87:189-96.

7- Guazzato M, Albakry M, Quach L, Swain MV. Influence of surface and heat treatments on the flexural strength of a glass-infiltrated alumina/ zirconia-reinforced dental ceramic. Dent Mater. 2005;21:454-63.

8- Guazzato M, Albakry M, Ringer SP, Swain MV. Strength, fracture toughness and microstructure of a selection of all-ceramic materials. Part II. Zirconia-based dental ceramics. Dent Mater. 2004;20:449-56.

9- Kelly JR. Clinically relevant approach to failure testing of all-ceramic restorations. J Prosthet Dent. 1999;81:652-61.

10- Larsson C, Vult von Steyern P, Sunzel B, Nilner K. All-ceramic twoto five-unit implant-supported reconstructions: a randomized, prospective clinical trial. Swed Dent J. 2006;30:45-53.

11- Löe H, Silness J. Periodontal disease in pregnancy: prevalence and severity. Acta Odontol Scand. 1963;21:533-51.

12- Luthy H, Filser F, Loeffel O, Schumacher M, Gauckler LJ, Hammerle $\mathrm{CH}$. Strength and reliability of four-unit all-ceramic posterior bridges. Dent Mater. 2005;21:930-7. 
13- Moher D, Schulz KF, Altman DG, CONSORT Group. The CONSORT statement: revised recommendations for improving the quality of reports of parallel-group randomised trials. Clin Oral Investig. 2003;7:2-7.

14- Naert I, Van der Donck A, Becker L. Precision of fit and clinical evaluation of all-ceramic full restorations followed between 0.5 and 5 years. J Oral Rehabil. 2005;32:51-7.

15- Raigrodski AJ, Chiche GJ, Potiket N, Hochstedler JL, Mohamed SE, Billiot S, et al. The efficacy of posterior three-unit zirconium-oxide-based ceramic fixed partial dental prostheses: a prospective clinical pilot study. J Prosthet Dent. 2006;96:237-44.

16- Reich S, Wichmann M, Nkenke E, Proeschel P. Clinical fit of allceramic three-unit fixed partial dentures, generated with three different CAD/CAM systems. Eur J Oral Sci. 2005;113:174-9.

17- Silness J, Löe H. Periodontal disease in pregnancy. II. Correlation between oral hygiene and periodontal condition. Acta Odontol Scand. 1964;22:121-35

18- Sjögren G, Lantto R, Granberg A, Sundström BO, Tillberg A. Clinical examination of leucite-reinforced glass-ceramic crowns (Empress) in general practice: a retrospective study. Int J Prosthodont. 1999;12:122-8.

19- Smedberg JI, Ekenbäck J, Lothigius E, Arvidson K. Two-year followup study of Procera-ceramic fixed partial dentures. Int J Prosthodont. 1998;11:145-9.

20- Studart AR, Filser F, Kocher P, Gauckler LJ. In vitro lifetime of denta ceramics under cyclic loading in water. Biomaterials. 2007;28:2695-705.

21- Suárez MJ, Lozano JF, Paz Salido M, Martínez F. Three-year clinica evaluation of In-Ceram Zirconia posterior FPDs. Int J Prosthodont. 2004;17:35-8.

22- Tuntiprawon M, Wilson PR. The effect of cement thickness on the fracture strength of all-ceramic crowns. Aust Dent J. 1995;40:17-21.

23- Vult von Steyern P, Carlson P, Nilner K. All-ceramic fixed partial dentures designed according to the DC-Zirkon technique: a 2-year clinical study. J Oral Rehabil. 2005;32:180-7.

24- Vult von Steyern P. All-ceramic fixed partial dentures: studies on aluminum oxide- and zirconium dioxide-based ceramic systems. Swed Dent J. 2005;173(Suppl):1-69.

25- Wassermann A, Kaiser M, Strub JR. Clinical long-term results of VITA In-Ceram Classic crowns and fixed partial dentures: a systematic literature review. Int J Prosthodont. 2006;19:355-63.

26- Yilmaz H, Aydin C, Gul BE. Flexural strength and fracture toughness of dental core ceramics. J Prosthet Dent. 2007;98:120-8. 